\title{
TENDENCIAS EN LA REFORMA PENAL $Y$ LECCIONES APRENDIDAS
}

\author{
ALFREDO CHIRINO SANCHEZ \\ Catedrático de Derecho Penal \\ Facultad de Derecho de la Universidad de Costa Rica \\ Director de la Escuela judicia!
}

\begin{abstract}
a que hoy presento tiene que ver con la situación espiritual del 1 derecho penal moderno, y con las posibilidades de éste frente a los retos del nuevo siglo. Se trata de una reflexión sobre los cambios que se estän sucediendo en el marco de la reforma penal de muchos paises del asî denominado "primer mundo". Un derecho penal que parece ceder a la tentación de reconducir sus esfuerzos por los mares tormentosos de una ley que ha ido perdiendo sus antiguas ataduras y limites, para convertirse en un derecho suave, flexible a las operaciones politicas y a los usos del poder, en una dimensión nunca antes vista.
\end{abstract}

Por ello, la ocasión es propicia para hacer algunas consideraciones adicionales, quizá modestas, sobre la situación del derecho penal costarricense, con el único fin de ubicar los flujos ideológicos existentes, y redondear algunos criterios que he expresado en otros lugares. El objetivo no es primariamente sentar un criterio univoco sobre la mencionada "situacion", que yo llamaria "espiritual" de nuestro derecho represivo, ni tampoco crear un nuevo frente en las difusas trincheras que han venido planteándose en nuestro debate penal, que parece desarrollarse al influjo de los prólogos que se hacen a diversas obras juridicas. Se trata simplemente de dar algunos pincelazos, casi sin detalle, sobre las operaciones que se realizan en nuestro margen con la herramienta coactiva del derecho penal.

Para hacer este diagnóstico voy a intentar, entonces, reflexionar acerca de algunas tendencias político criminales provenientes del así denominado "derecho penal de riesgos" y del "derecho penal simbólico",

\footnotetext{
${ }^{1}$ Hassemer, Winfried, Symbolisches Strafrecht und Rechtsgüterschut7, en: Hassemer, Strafen im Rechstaat, Baden-Baden, Nomos Vertagsgesellschaft, Primera Edición, 2000, pp. 170 y ss.
} 
que he utilizado en otras participaciones para referenciar la crisis del derecho penal de hoy, y ubicar las circunstancias en que se desarrollará la ciencia penal del futuro ${ }^{2}$.

\section{El Derecho Penal y la Comunicación}

Existe una relación directa entre el ambiente global de comunicación y las circunstancias que vive el derecho penal de hoy. Este se ha venido transformando para acogerse a los sutiles usos de la información, creando contextos a partir de imágenes que no se compadecen de situaciones complejas, sino de cuestiones más bien simples, donde resulta corriente justificar un uso del derecho penal, primordialmente en campos nuevos: como lo es el de la violencia doméstica, el acoso en el lugar del trabajo, pero también en la investigación genética y en la clonación.

La persona, al igual que el ambiente de la información, pasa a ser un fenómeno descentrado, esto es, pierde su posición central en el debate. El sujeto se interesa por la alteridad, y, en esencia, promueve una preocupación por el "otro". La lucha por saber del "otro" y de los "otros" potencia a los medios de comunicación, los cuales a su vez se alimentan con una cultura de la imagen. Ya no interesa el texto, sino la imagen: "una imagen dice más que mil palabras", parece ser el designio de esta verdadera "revolución" en el campo de la construcción de una nueva opinión pública.

La información de hoy no busca el convencimiento sino prefiere que el sujeto acepte lo informado. Se trata de un bien de consumo más. El derecho penal vende, en la medida que muestre violencia, desigualdad e imágenes de impacto. Por eso es una moneda de cambio común cuando se trata cle construir un "plan estatal" de combate al crimen. Aquél instrumento de venta se convierte, entonces, en una "respuesta" al crimen, a la inseguridad y a la incertidumbre planteada por la sociedad marcada profundamente por el miedo y el rechazo a los riesgos vitales que surgen por doquier.

Los ciudadanos son fácilmente convencidos de que la doctrina del "más de lo mismo" puede resolver los problemas más acuciantes de la sociedad. En general, se les convence de que el derecho penal puede ser un instrumento de conducción social, y que por medio de él se pueden establecer nuevas direcciones hacia más tranquilidad y paz.

\footnotetext{
2 En un texto posterior trataremos el problema del derecho penal cono ciencia, y sus posibilidades en el margen latinoanericano
} 
Lo cierto es que el derecho penal no alcanza a cumplir esta misión de paz y de conducción social. Su funcionamiento, más bien, contribuye a aumentar la violencia. Los conflictos que debe resolver son simplemente "decididos" por los órganos del control penal, y mantienen a la víctima satisfecha, inicamente con la angustia de su propia lesión y con un cambio en monetario por los daños y perjuicios que haya recibido.

El derecho penal de hoy intenta estabilizar la sociedad mediante sus designios normativos. Al mismo tiempo pretende convertirse en el timón social que otros campos del saber y de la politica no han podido ser, logrando con ello que este rama del derecho caiga en una crisis más profunda, tanto de legitimación como de funcionamiento, de la cual parece no haber salida.

Si se analizan los campos planteados por reforma penal se puede observar como el derecho penal sufre problemas hondos de "eficiencia" incluso en la tutela de bienes juridicos tradicionales como la vida. En concreto, el debate sobre el aborto, y recientemente sobre la clonacion, revelan que aun hay mucho que discutir acerca de las funciones reales y simbólicas del derecho penal, en especial si se toman en cuentan los defficit que aun mantiene en estos y otros campos en donde ha sido obligado a intervenir.

El deseo de "utilizar" al derecho penal se ha venido haciendo cada vez mâs fuerte, y hoy se mezcla con fines "eficientistas", los cuales pretenden crear una moneda común en el debate püblico sobre la politica criminal: "más eficiencia" significa, tambiên, "más derecho penal"3. Estos "usos" son particularmente claros en la arena politica, donde junto a la ubicacion, muy arriba, en la agenda politica del tema de la "seguridad ciudadana" se suele agregar a ese programa, el portentoso discurso del derecho penal "draconiano" y sin límites. Con su ayuda, es posible convencer a la ciudadania de que la estabilización social, la ansiada seguridad, y la eficiencia del sistema penal, sólo pueden lograrse con

\footnotetext{
${ }^{3}$ Con razón apunta Barreto Ardila que la "eficiencia" se convicrte asi en un fin del Estado, y por ende en una justificación de stı actividad. El sujeto no será más el fin del Estado sino que se tornará en un medio de alcanzar esa eficiencia, por lo que no habría meonveniente en restringir sus derechos individuales para satisfacer las expectativas de carácter colectivo. En este juego enloquecedor, cualquier bien jurílico con vocación de "social" imperará sobre fos derechos individuales. Es por ello que hoy más que nunca proliferan por doquier los bienes juridicos que deifican estos intereses colectivos, como la seguridad, el orden, la organización democrática. Barreta Ardila, Hernando, El sistemat penal en tiempos de redefiniciones etiológicas posmodernas, en: A.A.V.V., XX Jornadas Intenacionales de Derecho Penal, Bogotá, Colombia, Universidad Exlernado de Colombia, Primera Edición, Agosto de 1998, p. 20.
} 
más derecho penal, con más limitaciones de derechos fundamentales, los cuales al final terminan siendo transados fâcilmente, en un trueque violento y devastador para el Estado Democrático y Social de Derecho $0^{4} \mathrm{y}$ para el derecho penal que debe regir en el mencionado sistema.

Desde el punto de vista de una estrategia politica, el llamado hacia el derecho penal draconiano y al aumento de las sanciones y de la violencia estatal, es barato y no implica, en apariencia, grandes sacrificios económicos. Se trata de un "tigre de papel" que permite operar con sencillez y eficacia. Sin embargo, los costos de esta utilización se miden en disfunciones democráticas y en inconsistencia de las operaciones del sistema de justicia penal.

Además, este abuso del derecho penal tiene efectos contraproducentes en la sociedad. No se trata únicamente de una mayor cantidad de puniciones y de conductas formalmente penalizadas, sino tambiên de un catálogo mayor de posibilidades de criminalización que se anotan en el ya generoso listado de los Códigos Penales y de las leyes penales especiales. Con ello se eliminan los deberes de aquellos centros de decisión que deberian reaccionar con polititicas sociales de amplio rango.

\section{2. "Modemo" Derecho Penal}

En têrminos generales, la situación actual del Derecho Penal está caracterizada por un fenómeno de modernización. Dicho proceso viene clándose ya desde hace algunos años, periodo en el cual el Derecho Penal ha perdido su vinculación a los antiguos principios limitadores del Derecho punitivo, o dicho en otras palabras, el Derecho Penal se ha fugado de su centro de garantias y de limites del ius puniendi, que era, precisamente, la Constitución Estatal.

En palabras del Vicepresidente del Tribunal Constitucional Federal Alemán, Winfried Hassemer, estariamos viviendo un momento donde el Derecho Penal evolucionó y se ha convertido en algo contraproducente y anacrónico ${ }^{5}$. Esto último, no sólo porque muchas de sus teorias, instituciones y muchas de las formas en que se estructura la explicacion del Derecho Penal, son hoy a todas luces irreconocibles desde el punto de partida de la Constitución Estatal, sino también por la forma en que este derecho represivo busca legitimación.

\footnotetext{
"A diferencia de algunos autores nacionales, considero que sí existe la necesidad logmática de entender al Estado de Derecho como una mezcla efectiva de contenidos democráticos y de solidaridad. Más adelante haremos una intensa descripción de los argumentos a favor de esta tesis.

${ }^{5}$ Hassemer, Winfricd, Produkverantwortung in Strafrecht, Heidelberg, 1998.
} 
Algunos autores, entre ellos muy especialmente Bernd Schüneman, consideran que no ha habido, en realidad, ningún momento histórico donde el Derecho Penal haya sido especialmente iluminista y esencialmente bueno". De ahi deducen que no habria un momento histórico donde buscar ese derecho nuclear o clásico que tanto preconizan los autores de Francfort. No obstante, la búsqueda de HASSEMER y de la Escuela de Francfort no quiere entronizar una particular época histórica, sino plantear un retorno a un derecho penal más conforme con los dictados constitucionales, que pueda servir de faro de orientación para el legislador y el intérprete.

En todo caso, es evidente que el Derecho Penal en una etapa histórica mâs cercana a la Revolución Francesa era más proclive a pensar en términos del principio de legalidad, del bien juridico, del principio de humanidad de la pena y a trabajar con ideas de contencion y de limite al exceso. Algo que no podemos decir, a no dudarlo, del derecho penal moderno que vemos crecer por todas partes.

En uno de sus textos, nos refiere Silva SÁnchez una descripción de este fenómeno, al que èl denomina "expansión del Derecho Penal". Vive nuestra rama juridica un fenómeno de inflación que lo ha llevado a crecer sin limites, en la búsqueda de una tutela ampliada de bienes jurídicos más intangibles, supraindividuales y de carácter colectivo, y de meras cuestiones de desobediencia a deberes. Esto ha sucedido, fundamentalmente, en el derecho penal colateral (Nebenstrafrecht), al que algunos llaman "especialísimo" o el procedente de las leyes penales especiales. Esa parte de lo sancionatorio medra al margen del Código Penal, con una conciencia casi inmutable de que puede crear sus propios principios y reglas de interpretación. Esta ha sido la tónica, sì no nos equivocamos, en el campo del derecho penal económico, de la protección de la propiedad intelectual y, en algunos casos, del derecho tributario.

Entonces, si eso'es asi, efectivamente el Derecho Penal de hoy tiene más que ver con fenómenos de la mundialización, de actividades criminales que no tienen fronteras, que se organizan con las mismas reglas y condiciones de division del trabajo con las cuales funcionan todas las otras actividades económicas de los Estados y de los particulares. La criminalidad ha venido contribuyendo a hacer complejas las formas de comision de los hechos punibles, pero también ha hecho

\footnotetext{
"Schünemann, Bernd, Sobre la Situación Espiritual de la Ciencia Penal Alcmana, Bogota, Universidad Externado de Colombia, 2000.
} 
más complejo el derecho penal que ha sido preparado para su persecución. Se trataría de reducir algo de esa "complejidad" intrínseca, aumentando las redes de la criminalización, reduciendo garantias procesales para atacar a los "nuevos" enemigos, como lo fueron en su momento tanto el fenómeno del narcotráfico, y el de la criminalidad organizada y, recientemente, con el fantasma renacido del terrorismo.

Además ese Derecho Penal contraproducente y anacrónico empieza a desarrollarse también en la jurisprudencia. Poco a poco, de la mano de complejos casos de responsabilidad por el producto, han venido los tribunales europeos proveyendo a este "nuevo" derecho penal con una teoria de imputación que poco tiene que ver con las antiguas conexiones con la responsabilidad subjetiva por el hecho. En España es paradigmático el caso de la "Colza" y, en Alemania, lo son el caso del "Spray del Cuero", el asî denominado caso del "producto para preservar la madera" (Holzschutzmittel) y el caso "Contergan".

Estos casos tienen un único factor común, lo que ilaman ahora un elemento transversal, que es el decidir estos asuntos con un concepto de causalidad muy amplio, en los cuales simplemente no hay una imputación subjetiva de fácil deducción, como en los supuestos de causalidad natural. Se trata de sucesos en donde ha habido muertes y lesiones graves a diferentes personas, se tiene un. medio que aparentemente es sospechoso de haber causado la muerte y alguien que es responsable por su puesta a la venta y producción, y además el eterno problema del derecho penal: 1a deducción de una relación de responsabilidad con el hecho. En todos estos casos se demuestra que no se tomaron los recaudos y permitieron que el producto se siguiera vendiendo ocasionando más daño a las personas, a sabiendas que ya habia producido algunos problemas, pero los acusados alegaban que no era posible deducir una causalidad directa a partir del producto.

\section{Ia sociedad de riesgos como un paradigma de la construcción juridico penal}

Ha adquirido una relevancia inusitada, en el último tiempo, la discusión sobre una de las caracteristicas de este "derecho penal moderno". Se trata de su vinculación con una "sociedad de riesgos". Esto es de una sociedad profundamente marcada por riesgos vitales que surgen de creaciones de la humanidad, que parecen haber adquirido un cierto rango de independencia de sus creadores y que lo someten en términos de generar graves peligros para la vida de convivencia. 
Una sociedad sometida a los riesgos de un peligro inminente, generado a partir de las propias creaciones humanas para producir energia, estabilidad y bienestar debe buscar cómo controlarlos, en la medida de lo posible, e intentar reducir la incidencia de sus posibles efectos.

Aun ctiando dogmáticamente, aun no ha tenido una total recepción esta posición, ya se habla de un "derecho penal de riesgos" (Risikostrafrecht). En êl algunos autores como PRIrrwitz notan una sobrecarga en lo preventivo y, por ende, una utilización del instrumental del derecho penal para "reducir" riesgos potenciales, aun en una esfera adelantada a la producción de un eventual resultado lesivo.

Aun cuando no todas las sociedades de nuestro margen podrian contarse dentro de aquellas que gozan del dudoso distintivo de ser incluidas en el apelativo de "posindustriales", se habla, con alguna frecuencia, sobre todo en medios de comunicación colectiva de la necesidad de que nuestros gobernantes y politicos se interesen por "reducir riesgos", sobre todo de provenientes de decisiones y comportamientos humanos a la hora de utilizar modernos inventos industriales y tecnológicos en general.

A travès de esta sugerente utilización del idioma, plantean que deben reducirse los riesgos provenientes de la actividad criminal, y de ahi, un factor de riesgo social lo constituye también el ser humano. Esta operación es efectiva, especialmente, para tematizar el fenómeno de la criminalidad organizada, pero tambiên, y sobre todo ahora, el de la criminalidad común, como factor de riesgo para la seguridad ciudadana. Razön tiene Silva Sânchez en indicar que estos riesgos, no sólo los industriales y tecnológicos, tienen, la caracteristica de constituir un "fenomeno social estructural".

Las sociedades asi sometidas al temor sin limites a los riesgos, requieren de un derecho penal "curativo" y "preventivo". Este derecho no deberia de desistir de adelantar la tutela penal a esferas muy anteriores a la producción de un hecho delictivo (im Vorfeld einer Straftat), to cual bien. se puede lograr con una sobreutilización de los delitos de peligro abstracto, y con instrumentos de flexibilización de las categorias tradicionales de imputación subjetiva ${ }^{7}$. Esto ultimo rompe, por supuesto, con los presupuestos clásicos de imputación y con importantes principios garantistas del derecho penal ${ }^{8}$.

\footnotetext{
'Crr. al respectu: Alcácer Guirao, Rafael, La Prolección del Fattıro y los Daños Cumulativos, ent: RECPC 04-08 (2002), p. 3 disponible en formato PDF en: http://criminct.ugr.es/rect
} 
En suma, la sociedad de riesgos nos estaria preparando para construir un verdadero "Estado de Prevencion". Un Estado donde los derechos individuales tienen poca posibilidad de sobrevivir en el equilibrio forzado con los intereses sociales y colectivos, en una confusión entre legitimidad y seguridad, a la que nos hemos ido poco a poco acostumbrando ${ }^{10}$.

\section{La Teoria del Bien Juridico como limite o como pretexto}

En los años 80 del pasado siglo se creía que el bien juridico tenía una forma de legitimar el sistema penal, sometiendo al legislador a un límite insuperable, esto es, a señalar, con claridad, cual es el núcleo de la protección juridico penal. Sin embargo, la experiencia nos ha enseñado que "crear" un bien juridico tutelado es muy sencillo, tal y como si la tarea consistiera, simplemente, en buscar "debajo de las piedras" el ente o relación de protección que debe ser tenido en cuenta en cada tipo penal. Se ha observado que el legislador ya no encuentra ningún limite en esta operación, sino que, como en tantos otros campos, ha acudido al fácil expediente de crear bienes jurídicos "hechos a la medida" de la incriminación. Esto desbarata la función de limite del bien jurîdico y lo degrada a una mera herramienta operativa en los fines represivos que se ocultan detrás de estas operaciones. No obstante, debe tenerse claro que una cosa es un bien juridico elevado a factor de protección (que es casi una función metafisica del bien jurídico), y otra muy diferente es la relación personal que ostenta un ciudadano con un determinado ente o relación de convivencia, la cual debe seguir significando ejercicio de la libertad. Nuestra relación con los entes de tutela individual, como el honor, la salud, el derecho a la imagen o a la libertad sexual, es una relación personal orientada a realizar un plan de vida, una escogencia profundamente intima, y de ahi la importancia de la protección jurídico penal. Por eso, es que HASSEMER, por ejemplo, nos llama la atenciớn a que el bien jurídico es una relación de carácter personal y existe en la medida en que yo pueda realizar con él un determinado grado de libertad y autodeterminación en la sociedad.

SILVA SANCHEZ, parece recoger esta perspectiva, cuando considera que el bien jurídico sirve para proteger aquellos elementos esenciales del convivir social: "La idea clave, es pues, que sôlo pueden ser bienes jurídicos aquellos objetos que el ser humano precisa para su librê

\footnotetext{
${ }^{9}$ Así, Barrelo Ardila, op.cit., p. 14.

${ }^{10} \mathrm{lbid}$.
} 
autorrealización (que obviamente tiene lugar en la vida social), determinados objetos se convierten en bienes juridicos, por tanto, en la medida en que están dotados de un contenido de valor para el desarrollo personal del hombre en sociedad" ${ }^{11}$. Es decir, que ciertos objetos de protección, sobre los cuales ostentamos una determinada relación personal, se producen en la cotidianeidad de nuestra vida, se producen en relaciones comunicativas, en donde la interacción humana les da sustento y justificación.

La verdad es que el legislador no puede proteger una relación meramente metafisica, sino que debe intentar proteger una relación de libertad, esto es, una relación de la persona, que se realiza mediante el ejercicio de esa libertad concreta manifestada en el bien juridico. Este ejercicio del bien juridico es algo constatable y cuando la persona ha sido afectada por una infracción, el daño tampoco es metafísico, porque consiste en una lesión importante, una transgresion intolerable al ejercicio efectivo. Al menos esta lógica opera para los bienes juridicos que tienen carácter personal; en los bienes jurídicos inmateriales de carácter supraindividual como la buena fe, el orden público, el fisco, no sabemos en realidad quién es el titular, puesto que pueden servir a los intereses de una persona, pero también para el de un grupo de personas ${ }^{12}$. Ante estos bienes juridicos supraindividuales realmente no se puede usar la teoria de1 bien juridico personal, incluso Hassemer tiene que hacer modificaciones para sostener dicha teoria, porque ésta no se concilia fácilmente con la teoria de los bienes juridicos personales ${ }^{13}$. En efecto, ante una lesión de intereses colectivos ¿a quién habrá que buscar como victima directa? Es muy probable que nos encontremos la sorpresa de descubrit al Estado como la gran victima en estos delitos, y por ahi quizá tambièn se filtren expectativas de tutela colectiva leídas o extraídas de

"Silva Sánchez, Jesús Maria, Aproximación a los Problemas del Derecho Penal Penal Contemporáneo, Barcelona, Bosch, 1995.

${ }^{12}$ Cfr. Hefendehl, Roland, ¿Debe ocuparse el Derecho Penal de Riesgos Futuros? Bienes $J$ urídicos colectivos y delitos de peligro abstracto, en: Revista Electrónica de Ciencia Penal y Criminologia, RECPC 04-14 (2002), p. 3 disponible en fomato PDF en: hup://criminel.ugr.es/recp

${ }^{13}$ Hassemer, Winfried, Grundlinien einer personalen Rechtsgutslehre, en: Hassemer, Strafen, op, cit. pp. 167 y ss. Hohmann, discípulo de Hassemer, plantea la posibilidad de sostener los bienes jurídicos supraindividuales o colectivos en ta medida que realicen el desarrollo personal del individuo, una propuesta interesante para plantear su necesidad, cfr. Hohmann, Das Rechtsgut der Umweltdelikle, Frankfurt am Main, 1991, p. 189. La visión de Hassemer está bien planteada en: Hassemer, Winfried, Muñoz Conde, Francisco, Introducción a la Criminologia y al Derecho Penal, Valencia, Tirant Lo Blanch, 1989, pp. 108 y ss. Crítico sobre la proliferación de bienes jurídicos colectivos, Hassemer, Winfried, Derecho Penal Simbólico y Protección de Biencs Jaridicos, en: Pena y Estado, No. 1, 1991, pp. 31 a 36. 
aspiraciones sociales, en las que no estén bien concebidas libertades de carâcter personal. De hecho su comprension jurílica ha sido planteada a partir de su "no distributividad", es decir, de la calidad de no poder ser dividida en partes y de no poder asignar una porción de sus contenidos de tutela a éste o a aquél individuo ${ }^{14}$.

En todo caso, en los tiempos presentes debe el derecho penal proteger aquellos aspectos más esenciales de la persona como potencia suficiente, pues como lo plantea con razón Hassemer, el "negocio" del derecho penal no es, en esencia, el aseguramiento o la reducción de riesgos, sino la imputación de un hecho a una persona y la individualización de un problema, que sigue siendo también social: "...Los tiempos de una mayor profundización social significan para el derecho penal tiempos de una doctrina orientada a la persona"15.

\section{La inevitable crisis del concepto de persona en el derecho penal "moderno"}

No se sabe si el "Derecho Penal Cläsico" efectivamente existió, o si hubo una época anterior mejor para el espiritu de un derecho penal de garantias, pero sí podemos tener a un derecho penal orientado por la Constitución como un punto de óptica, como un eje comparativo, como un núcleo minimo de tutela, que nos sirva para establecer si un determinado tipo de Derecho Penal se aleja o no de ese centro de garantias y limitaciones, las cuales deben contar para el ius puniendi del Estado.

Visto de esta forma y considerando sus consecuencias, el Derecho Penal clásico podria coincidir con un derecho penal constitucional, cuya inspiración y orientación tendrian, en el decir cle ZAFFARONI, un verdadero horizonte de proyección antropológico ${ }^{16}$ : el derecho penal debe ser limitado par alcanzar una adecuada protección de los bienes jurídicos, y con ello de la libertad y la autodeterminación de los ciudadanos.

${ }^{14}$ Asi Kuhlen, "Der Handlungsbegriff der strafbaren Gewässerverunreinigung (Parágrafo $324 \mathrm{StGB}$ )", en: Goltdanuners's Archiv, 1 986, pp. 381, 396 y ss., citado por Hefendehl, op. cil., p. 4. De la Cuesta A.guado, por su parte, plantea otros criterios para la elaboración de biencs jurílicos colectivos, tomando como punto de partida, en primer lugar, el grado de adelantamicnto de la barrera de protección desde el punto de vista del bien jurídico básico, lo que obligaria a tener como punto de óptica a un bien jurídico individual. En el segundo criterio, basado en la sectorización de la protección, propone que se tenga también presente un bien jurídico individual, aun cuando reconoce que se puede llegar a grados de abstracción dondic, por el grado de alejamicnto que puede implicar esta tarea de tutela de bienes jurídicos, haya una vinculación lejana con el bien jurídico individual que notivó la tutela del legislactor. Cfr. De la Cuesta Aguado, Paz, Norma primaria y bien jurfdico: su incidencia en la configuracion del injusto (VII), en: http:/inicia.es/del gazented/norma32.htm

${ }^{15}$ Hassemer, Grundlinien, op. cit., p. 166.

15 Zaffaroni, Eugenio Raúl, Derecho Penal. Parte Gencral, Buenos Aires, 2000. 
En este "Norte" constitucional, habría entonces también límites para la interpretación del derecho penal. Los principios de interpretación "pro homine", "pro libertatis"17 o "pro libertate" 18 , y el de respeto de la dignidad humana, tienen, esencialmente, una orientación a la persona. De acuerdo a estos principios, cuando haya de ser interpretada una norma penal, con estricto apego a la Constitución, habria que tener en cuenta, en primer lugar, la proyección de la figura penal al ser humano (principio pro homine), y si hay que decidir entre libertad y castigo, y hay buenas razones para ambas, hemos de estar a favor de mayor libertad.

Finalmente, el principio de dignidad es un derivado natural del principio pro homine. El principio de digniclad, y también el de respeto a la autodeterminación, son ambos elementos esenciales de un horizonte de proyección del Derecho Penal. Según ZAFFARONi, ese horizonte de proyecciôn del Derecho Penal es un horizonte de desarrollo del Derecho

\footnotetext{
${ }^{17}$ Se trata de un principio de larga tradición en la interpretación de derechos fundamentales. En cl "Convenio para la protección de los derechos humanos y de las liberlades fundamentales" de Europa, por ejemplo, se incluyen normas generales, de interpretación a favor de la libertad, que vienen a completar las mucho más generales provenientes de las reglas de interpretación de los tratados, como las incluidas en la Convención de Viena sobre los Derechos de los Tratados (concretamente en los articulos del 31 al 33). En el Convenio Europeo sobre Derechos Humanos, se incluye un arlículo número 17 que contempla la regla "ninguna de las disposiciones del presente Convertio podrá ser interpretada de manera que implique para un Estado, un grupo o un individuo, un derecho alguno de entregarse a actividades o realizar un acto dirigido a la destrucción de los derechos y libertades reconocidos en este Convenio o a límites más amplios de estos derechos o libertades que los previstos en el mismo". Según el art. 18, "Tas restricciones que, en los términos del presente Convenio, llevan aparejados los mencionados derechos y obligaciones sólo pueden ser aplicadas segun el fin para las que han sido previstas". El art. 60, finalmente, establece que "no se interpretará ninguna de las disposiciones del presente Convenio en el sentido de limitar o disminuir los derechos humanos o las libertades fundamentales que pucdan estar reconocidos conforme a las leyes de cualquier Parte Contratante o de cualqutier otra Convención en la que-esta Parte Contratante sea parte". Estos articulos, a nuestro modo de ver, implican reglas de interpretación que obligan a los Estados parte de este Convenio a respetar los limites en que han sido reconocidas las libertades a los ciudadanos, los que implican, también la extensión de tutela al sistema democrático. Esto obliga a flevar la tulela de la libertad a una concordancia práctica o justo equilibrio entre los intereses del individuo y la sociedad democrática. El principio pro libertatis sugiere, entonces, una relación de tensión constante entre autoridad y libertad, y por esa misma razón debe tener en la interpretación penal una especial relevancia, que es lo que defendemos ahora. Cfr. con más teferencias Morenilla, José Maria, Naturaleza Del Convenio Europeo De Derechos Humanos y Ámbito de las Obligaciones de los Estados en La Jurisprudencia del Tribunal Europeo de Derechos Humanos, en: Consejo General del Poder Judicial, Jurisprudencia del Tribunal Europeo de Derechos Humanos II, Madrid, Espania, 1992, pp. 83-122.

${ }^{18}$ Diez Ripolles lo compara al principio "in đubio pro reo", indicando, con razón, que es un principio intimamente ligado a una sociedad en doncle ta libertad constituye mo de sus valores superiores. Por lo tanto, la función de este principio sería, precisamente, prohibir la penalización de esos cómportamientos sobre los cuales hay una duda fazonable sobre su lesividad social, pero también tiene consecuencus segun este autor, a la hora de discutir la legitinidad de las decisiones previas de penalización. Cr. Diez Ripolleśs José Luis, La Contexiualización del Bien Juridico Protegido en un Derecho Penal Garantista, eñ Revista de la..

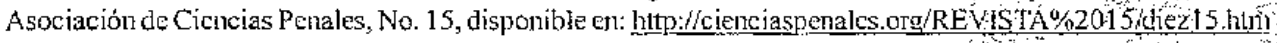

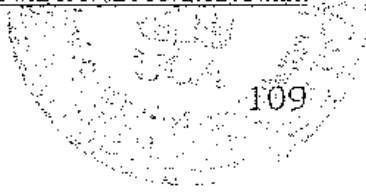


Penal, es decir, efectivamente es una meta hacia donde tender el Derecho Penal que es la realización de la persona y, por supuesto, a contener un determinado concepto de persona.

Es precisamente en estos aspectos donde notamos un abierto desgaste del derecho penal "moderno". Tanto en la dogmática derivada de sus presupuestos, como también en ciertas propuestas del derecho constitucional, vemos una tendencia, cada vez más fuerte a negar una concentración en los derechos subjetivos de los ciudadanos y ubicar el centro del interés regulativo y decisorio en los derechos que pertenecen a grupos o colectividades. La persona es en la medida que haya un grupo que la represente. Se trata de un sujeto de derechos que se ha "descentrado", y donde la existencia juridica depende de una representación grupal que bien puede no verificarse.

Como nos lo recuerda CHRistiE ${ }^{19}$, en la actualidad los Estados gobiernan a través del delito. En lugar de atender las necesidades de muchos desposeídos y afectados por las desigualdades del sistema, se prefiere, como en la politica de "zero tolerance", someterlos a persecución penal y a un castigo. Se trata de una verdadera "limpieza social" que adquiere un valor simbólico importantísimo: se trata de "nuevos" enemigos, que además son "convenientes" 20 . Algunos de ellos deben permanecer, especialmente los "enemigos ambiguos", los que no están bien definidos (verbigracia, la criminalidad organizada), porque ellos permanecen, legitiman una politica continuada en el tiempo y siempre permiten nuevas decisiones criminalizadoras y reductoras de derechos. Christie usa el ejemplo de la droga, pero hoy ha demostrado su "eficiencia" como enemigo, el terrorismo.

Pero ese individuo "descentrado", con el cual ahora se apertrecha una muy comoda politica, estamos ingresando en una teoria postmoderna de los derechos subjetivos ${ }^{21}$, es decir, ya no hablamos de derechos subjetivos, sino de derechos colectivos, de contextos grupales en donde si estoy representado por determinado grupo existo.

Cuando se vacia del contenido de libertad, por ejemplo, en el concepto de intimidad, simplemente para facilitar la investigación de ciertos

\footnotetext{
${ }^{19}$ Christie, Nils, El derecho peral y la sociedad civil. Peligros de ta sobrecriminalización, en: A.A.V.V., XX Jornadas Internacionales de Derecho Pesal, Bogotá, Colombia, Universidad Externado de Colombia, Primera Edición, Agosto de 1998, pp 52 y ss.

${ }^{20}$ Ibid., p. 53.

2t Representada, entre otros, por Karl-Heinz Ladeur, Profesor de la Universidad de Bremen cn la República Feđ̌eral de Alemania.
} 
delitos, se produce claramente un vaciamiento del nucleo esencial de tutela de la "intimidad" a partir de un interés colectivo como lo puede ser la "seguridad" o la "funcionalidad de la administración de la justicia".

Los cambios procesales experimentados en los íltimos años, para ampliar Ias posibilidades de investigación, especialmente de la policía y del Ministerio Público, demuestran el descrédito que sufren los derechos ciudadanos cuando son sopesados con esos intereses colectivos, reforzados por la aspiración de seguridad que nuestras sociedades modernas manifiestan ${ }^{22}$.

\section{Constitución y Reforma Penal}

Llegados a este punto, podriamos preguntarnos cuáles son los alcances de una observación constitucional de la reforma, y si ella puede darnos alguna clave para orientar o reorientar esfuerzos para el derecho penal especial.

Estas preguntas son válidas desde que conforman, creemos sinceramente, la preocupación costarricense por los cambios en su derecho penal, y deberiamos estar en capacidad de responderlas con el modelo de tutela que contiene nuestra Carta de 1949.

Coincidimos con aquellos que opinan que la configuración constitucional de un Estado Democrático de Derecho es, en realidad, una propuesta para transformar el status quo (asi Gomes Canotilho ${ }^{23}$ ). Esa transformación del status quo implica, por una parte, fortalecer la tutela de los derechos fundamentales contenidos en la Carta, así como promover la justicia social mediante la consecución de una sociedad libre, justa y solidaria.

Esta lucha, y esta relación de tensión, implican ponderar libertades individuales y responsabilidades colectivas, en una lógica constitucional que no deja de lado la preocupación por las desigualdades económicas y sociales.

No es fâcil lograr una concordancia práctica entre estos valores, pero es la lucha verdadera en un Estado Liberal, y contempla, en términos

\footnotetext{
22 Ya hemos realizado un diagnóstico preliminar de esta situación en: Chírino, Alfredo, La "criminalidad organizada" como un nucvo topos de la política de seguridad y orden. Algunas Consideraciones sobre los canbios procesalcs surgidos del impetu de esta politica, en: Llobet Rodriguez, Javier y Chirino Sánchez, Alfredo, Principio de Oportunidad y Persecución de la Criminalidad Organizada. (Problemas Prácticos e ideológicos de un proceso penal eficiente), San José, Arcté, pp. 151 y ss.

23. J. J. Gomes Canotitho y Vilal Moreira, Fundamentos da Constituiçăo, Coimbra Editora, 1991, p. 86, citado por: Semer, Marcerlo, Projeções Constilucionais para a Reforma Penal, en: http://www.pge.sp.gov.brt centrodeesludos/revistaspge/tevistás/5rev7.htm
} 
generales, la descripción de la lucha en el derecho penal por realizar aun fines de tutela individual y proteger fines de carácter colectivo cuyos riesgos más importantes son los que se producirán a futuro ${ }^{24}$.

El derecho penal que proviene de esta interacción, contiene estos ingredientes: se trata de un derecho penal contenido y al mismo tiempo consciente de sus límites. El lector podrá preguntarse, adicionalmente, donde podemos encontrar un derecho penal con tales caracteristicas, si como hemos dicho, el derecho penal moderno se caracteriza precisamente por haber perdido esa conexion. Pero insistimos, estamos hablando aquí de una propuesta para reconstruir al derecho penal, y sujetarlo como al Leviatán a las ataduras constitucionales. Su poder gigantesco no puede seguir libre para crear afectaciones a derechos esenciales de la convivencia para cumplir con una promesa irreal de seguridad.

Cuando el derecho penal recobra su vinculación constitucional, recobra, al mismo tiempo su sometimiento a una serie de limites materiales para su construcción y funcionamiento. Uno de estos elementos limitadores lo es sin duda, el concepto de bien juridico ${ }^{25}$.

La necesidad de una reforma penal, o de la introducción de nuevos tipos delictivos, o de redefinir una politica de persecución penal, se legitimaria por la necesidad de tutelar a los bienes juridicos más esenciales para la convivencia humana de las lesiones más importantes que puedan sufrir.

En una coyuntura como la actual donde impera la orientación normativa, el bien juridico sufre en su función limitadora, ya que las expectativas sociales bien pueden rebasar los limites usualmente entendidos para el derecho penal.

Las Constituciones latinoamericanas suelen fundarse en el respeto a la dignidad humana, dicha orientación implica, entre otras cosas que no se debe desistir de la tutela de la libertad con el fin de tutelar fines que no estên basados en objetivos tambièn protegidos por la Constitución. Hacerlo implica, de hecho, desproteger en todos los casos el contenido propio de la libertad y de la dignidad humana.

Asi, el derecho penal no puede, por principio, derogar ámbitos de libertad del ciudadano, para castigar meras desobediencias a mandatos normativos, inspirados meramente en bienes juridicos insustanciales,

\footnotetext{
${ }^{24}$ Así, Hefendehl, op. cit., p. 5

${ }^{25}$ Măs detallado al respecto HefendehI, op. cit., p. 6.
} 
tales como: la seguridad del estado, el bienestar de la sociedad, el orden público.

En el ültimo tiempo hemos observado un intenso esfuerzo legislativo por construir un derecho penal de deberes, muy cercano al derecho administrativo sancionador, donde el contenido de la incriminación se satisface en la descripción de un deber que hay que cumplir, y que si se incumple, por ese mero hecho ya habria una lesiôn antijuricica. Un derecho penal basado en la protección de tales deberes saca de su centro de atención al bien juridico e instaura a la norma como el Norte esencial de protección. De ahí la queja de muchos penalistas por la "administrativización" del derecho penal, un fenómeno cada vez más intenso.

El derecho penal del Estado Democrâtico y Social de Derecho está limitado por principios constitucionales de considerable estatura y trascendencia como lo son los de legalidad, lesividad e intervenciôn minima.

E1 dictado de estos principios permite, en primer lugar, ubicar al bien juridico como la construcción teórica y práctica más importante que se deriva de la Constitución. Su inclusión en los Proyectos de Código Penal de la region, como sucede en el de Costa Rica y el de Honduras, por ejemplo, parece no ser casual, ante la necesidad de hacer evidente esta relación que proviene del derecho constitucional ${ }^{26}$.

El principio de lesividad, en una concordancia práctica con el principio de intervención minima, ordena que el derecho penal solo debe proteger aquello que sea esencial para la vida de convivencia. Se trata de una orden para el legislador a la hora de pensar la inclusión de un nuevo tipo penal o de intentar incluir para su castigo penal nuevas conductas. No todo puede ser objeto de tutela penal, no en vano se debe seguir concibiendo al derecho penal como un "orden discontinuo de ilicitudes".

\footnotetext{
26 Eliminar este supuesto del Código Penal implica, desue nuestra óplica, un esfuerzo vano, ya quac la necesidad de lesividad seguirá existiendo, sobre todo si se hace una lectura integral del articulo 39 con el artículo 28, segundo párrafo de la Constítución Política. Solo aquellas relaciones de convivencia importantes podrán ser tuteladas por el derecho penal. Asi también, solo las afectaciones importantes, realmente lesivas a csios bienes juridicos, son las que legitimamente puede perseguir y sancionar el sistema de justicia penal. En las discusiones de la reforma penal costarricense se ha sostenido que no es neccsario incluir ch "principio de lesividad" como un principio en la Parte Geteral del Código Penal, toda vez que se deduce de los Tratados y Convenios en materia de Derechos Humanos, suscritos y ratificados por el pais, cosa que es cierta. Sin embargo, un recordatorio al intérptete en el Código Penal no hace daño, sobre todo cuando tuvimos tantos años donde solo mencionar al bien juridico significaba en nuestra justicia penal, mencionar un fantasma que solo existía en los texlos de enseñanza en las Universidades y se creia que no tenia ninguna incidencia en la aplicación práctica de las disposiciones penales.
} 
Por supuesto, las politicas criminales de los últimos tiempos, con un profundo carácter populista, operan con el derecho penal en contra de estos dictados constitucionales, y por ende resulta necesario luchar contra estas tendencias con el arma de la lucha constitucional. E1 derecho penal inflacionario debe ser contenido con una lectura atenta de los principios de lesividad y de intervención minima, de los cuales se derivan otros cuidados y advertencias al legislador.

Por más loables que sean las intenciones de lograr una cierta moral en el trabajo y en las relaciones humanas, alcanzar fines morales por la via del derecho penal siempre ha sido insatisfactorio y promueve una derrota del sentido general del derecho penal. No obstante, son frecuentes las sugerencias del legislador de combatir el acoso en el litgar del trabajo por la via penal, asi como también incluir en la legislación disposiciones sobre el recato sexual y también sobre el correcto comportamiento familiar, para citar tres muy recientes en las propuestas legislativas en nuestro país.

Un derecho penal comprometido con un "orden discontinuo de ilicitudes" no puede, en modo alguno, intentar servir para promocionar la inflación penal. La correcta instrucción que nos envia este principio es la de buscar otras fuentes de control social o incluso una politica social que promueva una mejoria en esos sectores que, sin duda, requieren atención del legislador.

No es legitimo, constitucionalmente, alcanzar la paz y la seguridad a cualquier costo, incluso al costo de las libertades y garantias individuales. Es por ello que creemos que un derecho penal que respete estas sujeciones constitucionales no puede promocionar la pena de muerte o las penas largas de prisión o, incluso, las reducciones importantes que están sufriendo las garantias y derechos del justiciable en el proceso penal "eficiente" de nuestros dias.

Todas estas ideas chocan con el "uso" que se hace modernamente del derecho penal. El derecho penal que deberia ser ultima ratio se ha convertido en "primera y única ratio", y ante esas circunstancias debemos afrontar las disfunciones que un derecho penal de esta naturaleza promociona.

Un derecho penal de corte populista busca su legitimidad en una dramatización de la violencia, nos lo recuerda correctamente DYRCEU Aguiar Dias Cintra Junior ${ }^{27}$. Se trata de una propuesta coactiva que

${ }^{27}$ Dyrceu Aguiar Dias Cintra Júnior, OJudiciário brasileiro em face dos direitos hunanos, Justiça e Denocracia (Publicação oficial da Associação Juizes para a Democracia), n. 2, jul./dez. 1996, ciłado por, Semer, op. cit. 
responde exclusivamente al valor de cambio de esa "violencia" y a cómo ésta es presentada a la población. Se trata de un derecho penal efectista y con fines exclusivamente simbólicos. Sus caracteristicas măs prominentes son los frecuentes proyectos de reforma penal en la Parte Especial y el aumento exagerado y desproporcionado de los montos de pena que suelen acompañarles.

Otro criterio para derivar una politica criminal de la Constitución lo constituye, sin duda perseguir una proteccion integral y coherente de los derechos humanos. Las Constituciones de la región suelen hacer referencia, sobre todo aquellas derivadas de los procesos de cambio constitucional a partir de los años ochenta, a los derechos humanos y a su validez inmediata. Entre otras consecuencias implica hacer realidad la prohibición contra los tratos crueles y degradantes como forma de pena, prohibir la tortura y castigarla como delito, o consignar en la Parte Especial una correcta tutela de los bienes jurídicos de la Humanidad.

El Proyecto de Código Penal para Costa Rica, que ha sido recientemente dictaminado en la Asamblea Legislativa ${ }^{28}$, ya contiene esta orientación, no sólo en el sentido de integrar el Derecho Penal Humanitario en la estructura de la Parte Especial, sino tambiên en el sentido de incluir la prohibición de la tortura y un sistema de penas alternativas a la prisión que pretenden, en términos materiales, la reducción los efectos nocivos de las penas cortas de prisión, y aumentar el marco de posibilidades de individualización sancionatoria.

La protección de los derechos humanos también obliga a poner en términos muy claros un alto definitivo a la "administrativización" del derecho penal, por la via rápida de introducir, sobre todo en leyes penales especiales, tipos penales que castigan, exclusivamente la desobediencia a mandatos de carácter normativo

El derecho penal de un Estado Democrático y Social de Derecho tambiën debe privilegiar el respeto a un ámbito libre de regulación juridica. Coincide este objetivo con el principio de mínima intervención, en el sentido de conceder ámbitos mayores de libertad al ciudadano, no criminalizando esferas donde aun no se ha cometido una lesión a un bien jurídico o donde el peligro para este último sea demasiado contingente. Una forma de lesionar esta aspiración lo seria castigar formas de pensamiento, o actitudes morales. Es por ello que se discute

${ }^{28}$ Estas notas de presentación se han conçuido en mayo de 2003, luego de que la Comisión de Asuntos Juridicos de la Asamblea Legislativa decidió, finalmente, dictaminar el Proyecto de Código Penal. 
hoy en dia sobre la conveniencia de no incluir en los listados de delitos de la Parte Especial a dos figuras que han hecho una larga trayectoria, y que hoy cuentan, desgraciadamente, con buenas oportunidades de continuar incluidos alli, justificados por sus posibles papeles en la lucha contra el terrorismo, se trata, a no dudarlo de la "asociación ilicita" y 1a "apologia del delito".

Este principio de intervención mínima también debe ilustrar al legislador sobre la inconveniencia de criminalizar, directamente, ciertas formas de protesta civil. La democracia vive de la tension entre las aspiraciones populares y las actitudes de los gobiernos. La no coincidencia en muchos puntos de vista, sobre todo en aquellos que implican medidas impopulares, genera amplios procesos de protesta que alimentan el debate público y generan cambios. Criminalizar esta protesta y reducirla con el garrote policial parece el camino del facilismo politico. Está claro que un derecho penal republicano no puede pretender una resolución de todas las diferencias siempre a favor de la autoridad y del poder.

Estos conflictos de autoridad y libertad también se observan en la punición del desacato a las autoridades püblicas. Dichosamente e1 camino hacia la desaparición de esta figura de los Códigos Penales ya se ha abierto, y en varios paises, Costa Rica entre ellos, ha sido eliminada del catálogo de la Parte Especial. El desacato no era más que una subordinación del ciudadano a la autoridad del gobernante, lo que no era justificable descle ningún punto de vista, y su sanción desafiaba todo juicio de proporcionalidad.

El mismo destino del desacato lo han tenido también las figuras que castigaban la vagancia, la mendicidad y el abandono, así como también el alcoholismo y el homosexualismo. El derecho penal de la democracia no puede imponer una moral social, mucho menos la adopción de prácticas sexuales o de determinados comportamientos frente al trabajo, sobre todo cuando éste es cada vez más escaso y un efecto colateral indeseable de las mismas políticas económicas neoliberales. Ni el criterio de alcanzar tuna fuerza configuradora de las costumbres (Welzel), ni el de un pretendido efecto de psicologia social ${ }^{30}$, podrian justificar los

\footnotetext{
${ }^{25} \mathrm{Al}$ respecto, Quintero Olivares, Gonzalo, La Climinalidad Organizada y la Función del Delito de Asociación Ilicita, en: Ferré Olivé, Juan Carlos y Anarte Borallo, Enrique (Editores), Delincuencia Organizada. Aspectos Penales, procesales y criminológicos, Huelva, España, 1999, pip. 181 y ss.

${ }^{30}$ Descriptivo sobre los problemas de racionalidad del castigo, tomando como punto de partida los principios establecidos por H.L.A. Hart cfr. Fletcher, George, Rethinking Criminal Law, New York, Ox ford University Press, 2000, pp. 414 y ss.
} 
efectos exclusivamente simbólicos que este tipo de incriminaciones pretenden ${ }^{31}$. A la larga, como algunos autores lo expresan, la sobrecarga simbólica del derecho penal provoca una enorme disfunción y prepara el camino para que la crisis del castigo penal se profundice, hacièndole perder toda fiabilidad por su gran violencia en ciertos grupos de poblacion y su ineficacia general ${ }^{32}$.

La importancia del tema de género, por ejemplo, no ha escapado al debate penal. Podemos decir, sin temor a equivocarnos, que éste tema ha llevado a la palestra de discusión aspectos largamente relegados de la optica de los penalistas. La significación del problema no puede bagatelizarse con un simple acercamiento de igualdad, sin embargo, estả claro que el mismo concepto de victima jurídico penal, sobre todo en delitos sexuales, ha ido sufriendo en los últimos años una trasformación profunda. Un buen ejemplo de ello es el delito de Violación, donde la construcción tipica actual permite su comision por hombres y mujeres, pero tambien la victima puede serlo también un hombre. Dichas circunstancias permiten, por supuesto en una base muy preliminar, analizar como el discurso del gènero ha provocado cambios importantes. Sin embargo, el camino recién se inicia bajo el influjo de los vientos constitucionales dirigidos a propiciar un debate rico sobre las libertades individuales y el respeto a la dignidad humana, por lo que el análisis del jurista debe estar dirigido ir construyendo sensibilidad por estos problemas y romper con la inequidad de género, cuya permanencia en la legislación provoca ya un rompimiento con principios valiosos de la Carta Fundamental.

\section{Algunas tendencias de la Parte Especial y un diagnóstico de la situación}

\section{a. La protección de la vida y la manipulación genética}

Se trata sin duda de uno de los aspectos de la discusión penal que más preocupa, y que siguen en la mesa de discusión, profundamente involucrados con temas de filosofia del derecho.

La perspectiva propuesta por el autor nos llamó mucho la atención, y quisimos hacer un planteo de algunas de sus consecuencias, tratando de enmarcar algunas de las cuestiones desde la perspectiva del debate

\footnotetext{
${ }^{31}$ Luzón Peña, Diego Matuel, Función Simbólica del Derecho Penal y Delitos Relativos a la Manipulación Genética, cn: Revista Documentos Penales y Criminológicos, Managua, Nicaragha, Volunen 1, Año 2001 , pp. 12 y ss.

${ }^{32} \mathrm{Cfr}$. Chitino, Criminalidlad Organizada, op, cit., pp. 183 y ss.
} 
que se ha generado en el pais sobre el tema de la clonación, de la fertilización in vitro, y otras manipulaciones de la información genética de los seres humanos.

Los trabajos de los médicos Hali y Stillman en el Centro Médico George Washington, en el año de 1993, despertaron un furioso interés del debate juridico y politico. Se trataba de los primeros procesos investigativos en relación con embriones humanos y la posibilidad de trabajar directamente con el núcleo celular. Sucesos posteriores de 1997 y 1998 nos pusieron a la defensiva ante la posibilidad de clonar animales y, por qué no, tambiên seres humanos.

El legislador, en el derecho comparado, no ha esperado mucho para buscar una tutela de los embriones. En la República Federal de Alemania se puso en vigencia la Ley de Protección de Embriones ${ }^{33}$ en el año de 1991, la cual se apresuró a prohibir la clonación de seres humanos ${ }^{34}$. E1 legislador germano intentô prohibir que de manera artificial se pudiera permitir que un embrión humano pudiera contener la misma información genética que la que proviene de otro embrión, un feto, una persona o un muerto. La pena puede liegar hasta cinco años de prisión. De la misma forma se castiga, por ejemplo, quien trastada a una mujer un embrión en esas condiciones.

Se entiende que el legislador pretende, por este medio; prohibir la reproducción de copias exactas de un ser humano, generadas de manera artificial, por medio de las técnicas de la clonación.

La protección del embrión en la legislación alemana es amplisima, ya que la protección de éste se origina desde la introđucción del espermatozoide en el óvulo hasta la culminación del proceso de fecundación.

El ejemplo alemăn de una protección total desde el momento de la introducción del espermatozoide en el ovulo, no ha sido la tónica en todos los argumentos. El mismo Comité Consultatif d'Éthique pour les Sciences de la Santé, de Francia, creado en 1983, caracterizó al embrión como un potencial ser humano, merecedor, a pesar de ello, de protección.

También la jurisprudencia comparada ha tenido altibajos en el reconocimiento del embrión como un sujeto de derechos. El caso Roe vs. Wade en los Estados Unidos de Norteamérica dejó abierta la cuestión ante la Corte Suprema de Justicia, la cual decidió, con fundamento en

${ }^{33}$ Embryonenschut $\angle$ geset 2 (EschG) del 1 de enero de 1991.

is Concretamente en el parágrafo 6 . 
los derechos de la madre, concretamente el de privacidad y el de libre elección y decisión sobre el propio cuerpo, que quien está por nacer no es una persona, y, por lo tanto, no es un sujeto de derecho, el cual sólo recibe protección del orclenamiento juridico hasta el ultimo trimestre de la vida, y solo en forma relativa. El Tribunal Consticucional español, siguiendo estas lineas argumentativas, consideró que el por nacer no es titular de un derecho a la vida, y que éste es un derecho que solo es imputable a los nacidos, llegando a la curiosa conclusion de que quien está por nacer recibe una protección del ordenamiento en tanto y en cuanto es considerado un bien juridicamente protegido.

Tambiên se ha intentado establecer una diferencia entre preembrớn y el embrión, con el objetivo de establecer una diferencia ontológica con el huevo que aun no anida en el útero de la madre. Esta diferencia, puramente metodológica, no atiende al hecho biológicamente demostrado de que desde el momento de la concepción el ser tiene su propio código genético, el cual lo acompañarâ durante todo el proceso de formación y gestación y por el resto de su vida. Teóricamente, los que sostienen la posición contraria, dicen que la vida humana existe desde un momento posterior a la fecundación, casualmente catorce dias después de este suceso, cuando se produce la anidación en el útero materno y surge en él la asi denominada cresta neural, comenzando la formación de los órganos del nuevo ser. Por supuesto, antes de todos estos sucesos no existiria un ser merecedor de tutela a su derecho a la vida, y solo sería considerado como una mera amalgama de células carentes de individualidad. Agregan a sus argumentaciones que esto es asi, porque dicho conglomerado de células, por ejemplo, aun no da idea si se formará un solo ser o dos, como es el caso de los gemelos monocigóticos. Este último argumento cae por su propio peso, ya que la mencionada división no deja abierta la posibilidad sino a la formación de personas, por lo que desde el punto de vista de discusión no estamos ante la posibilidad irregular que la mencionada división dé como resultado algún otro producto no calificable de persona. Podemos considerar también el argumento biológico sostenido por observaciones cientificas recientes que la individualidad de los gemelos monocigóticos no proviene de puros datos del genotipo sino también del fenotipo. La individualidad se funda en la singularidad de un ciclo vital y no sobre el carácter univoco del genoma. El individuo existe y se comunica con su entorno, lo que nos permite rechazar, por los menos preliminarmente, la conclusión sostenida por un autor nacional de que "sólo la comunicación puede comunicar" que pretende excluir a los sistemas subjetivos de capacidad de comunicación autónoma con el medio social. 
Ya nos referiremos en otra parte a esta singular conclusion propia de un cierto tipo de solipsismos epistemológicos, como bien los denomina el querido colega JoRGe LUIS ARCE VIQvez, al referirse, informalmente, por supuesto, a algunas posturas del debate sobre la ciencia penal en Costa Rica ${ }^{35}$.

Observaciones provenientes del Congreso "En los Albores de la Vida Humana", organizado por el Instituto de Ginecologia y Obstetricia de la Universidad Católica de Roma, que se llevó a cabo en el Vaticano hace casi tres años, en septiembre de 2000 , indicaron que desde la primera fase de la subdivisión celular, cuando el embrión ya transita a través de las trompas de Falopio para anidarse en el utero materno, es decir, antes de los catorce dias tantas veces citados, ya éste realiza intercambios y comunicaciones con su ambiente, los cuales suceden por contacto con los tejidos de la madre, donde se puede mencionar que se da una verdadera comunicación celular y biológica, ya que dichos intercambios también se dan por la via sanguinea. Los mensajes que intercambia el embrión y la madre no podemos decir que provienen de los que son conocidos por el sistema nervioso central, ya que desde el punto de vista del embrión este aun no está presente, pero muy probablemente dichos mensajes son diferenciables de los provenientes de otras especies y que pueden llamarse dignamente humanos, que usan como autopista de movimiento no sôlo las sustancias quínicas especiales sino también las cèlulas denominadas estaminales. Dicha comunicación, entre otras cosas, genera que el embrión no sea rechazado por la madre, un ser, dicho sea de paso que es diferenciable genéticamente al menos en un $50 \%$ de la madre.

Cono esperamos haber clejado clarificado, la diferencia entre preembrión y embrión no tiene otro sentido que permitir la manipulación de un ser vivo dentro del periodo de catorce dias necesario para la anidación, de ahi que denominemos a la diferencia como de carácter metodológico pero no ontológica. Se busca una justificación para la operación, manipulación y otras intervenciones en el embrión antes de la anidación. Por otra parte, quién ha establecido este plazo de catorce dias, lo hace por consenso, se trata de algo totalmente artificial, que busca facilitar la investigación científica en el embrion. Es posible citar investigaciones recientes y autores que sostienen que incluso la anidación se puede producir antes del plazo de catorce dias.

\footnotetext{
${ }^{25}$ Quizá pos no estar escritos no existen, pero su profundidad se realzó al repensarlos con una taza de cafć, igracias torge!
} 
La ya citada Ley de Protección de Embriones alemana, también se refiere al tema del momento en que es considerable, juridicamente, estar en presencia de un embrión. Menciona el parágrado 8, número 1, de esta ley que "...se considera embrión...el ovvulo humano ya fecundado y capaz de desarrollarse, a partir del momento de la fusión nuclear, asi como toda célula pluripotencial extraida del embrión que, dada las condiciones ulteriores indispensables para ello, pueda seguir dividiéndose hasta desarrollarse en un individuo".

E1 número dos de este parágrafo ocho de la Ley alemana prevé, adicionalmente, que "...en las primeras veinticuatro horas siguientes a la fusión nuclear se considerará susceptible de desarrollo al ovulo humano fecundado, a menos que, antes de la expiración de ese plazo, se compruebe su incapacidad para pasar de su fase monocelular".

En todo caso, y aunque consideremos correcta la posiciôn del legislador alemán, de no hacer distinción entre preembrión y embrión, si existe un problema interpretativo sobre el asunto de la transmision de información genética, que es un tema que toca directamente el problema de la aplicación jurídico penal del tipo penal de manipulación genética. En efecto, al mencionar el tipo penal la frase "misma información" estará planteando una dificil cuestión técnica referida a los métodos de transferencia. Esto último, por ejemplo, porque por medio del "splitting" de embriones puede transferirse información idèntica, en otras técnicas solo se transmite el $99 \%$ de la información genética, esto último, en el caso del método del Instituto Roslin. El resto de la información proviene del material mitocondrial de la célula portadora ${ }^{36}$.

A la luz el principio de legalidad es esta situación de la descripción bastante complicada y aun en el contexto de la Constitución Alemana casi irresoluble, ya que abre la puerta a una analogia prohibida.

Iguales problemas acarrea, por ejemplo, el término "embrión", como ocurre en la Ley Alemana, ya que amplia el concepto de embrión de tal forma que algunas formas de clonacion, como la proveniente del Instituto Roslin, podrian considerarse prohibidas aun cuando no implica una combinación total del núcleo.

La situación destacada en Alemania, no podria dejar de esperarse en otros paises de la Unión Europea. El 12 de enero de 1998 se suscribiría

\footnotetext{
${ }^{36}$ Cfr. Gutmann, Thomas, Strafbarkcit des Klonens von Menschen, en: Roxin/Schroth (Editores), Medizinstrafrecht. Im Spannungsfeld von Medizin, Ethik und Strafrecht, Stuttgart, München, , Hannover, Berlin, Weimar, Dresden, Boorberg Verlag, 2a. Edición, p. 354.
} 
por 19 de los 40 Estados miembros un protocolo adicional a la Convención de Bioética del Parlamento Europeo, el cual, prohibe, expresamente, la clonación de seres humanos.

La ventaja de la regulación europea es que no introduce la complicada fórmula alemana de la "identidad de la informacion" y se conforma con la información que se traslada a nivel no mitocondrial.

En el ámbito de las Naciones Unidas y la Comisión de Derechos Humanos de la Naciones Unidas se plantean, también, el tema.

En la actualidad hay normas en contra de la clonación đe seres humanos en Gran Bretaña, Dinamarca y España, pero también en Argentina y Australia.

La línea regulatoria se orienta a proteger el embrión humano fuera del vientre de la madre, sobre todo en los casos de embriones crioconservados. No obstante, existen en algunos paises (como por ejemplo Alemania) algunas regulaciones generosas que permiten el aborto del feto, lo que conlleva a destruir lo que tantas convenciones intentaban proteger fuera del vientre materno. La contradicción se hace manifiesta cuando se le pretende reconocer al embrión una serie de derechos y garantias, como el de la dignidad y el de subjetividad, pero solamente si esta fuera del vientre de la madre. Cuando se encuentra centro de ella ya no recibe igual tratamiento ${ }^{57}$. Es por ello que esta línea regulatoria se manifiesta especialmente en los paises que admiten la interrupción voluntaria del embarazo, sobre todo en las primeras semanas luego de la concepción.

Uno de los problemas mảs arduos a los que se enfrenta el legislador penal es la definición del bien jurídico tutelado en los tipos penales que castigan la "manipulación genética". Mucho más complicado se hace, sobre todo, cuando se toma en cuenta que las asî denominadas "manipulaciones" recaen sobre el patrimonio genético del embrión, sobre todo sobre sus células germinales, 10 que implica, además una contradicción evidente con el derecho a la dignidad humana, la cual cubre, naturalmente, el patrimonio genético humano.

No se trata de prohibir, digámoslo de nuevo, la investigación cientifica, si no de someterla a limites concretos, sobre todo de los que provienen de la integración sistemática de los principios de protección a la dignidad humana y a los caracteres de la personalidad del individuo.

"S Sambrizzi, Eduado, La Procreación Asistida y la Manipulación del Embrión Humano, Buenos Aires, Abeledo-Perrot, s.f.e., p. 
Por supuesto, que esto toca duramente la cuestión de como ponderar los derechos a la investigación y a la información y el derecho el individuo a ser protegido en su dignidad. Este equilibrio de derechos fundamentales no es fácil, y estamos acostumbrados a sus difíciles ponderaciones como lo demostró el colega JAVIER LLOBE $T$, también entre nosotros, sobre el tema de la prisión preventiva, en su obra aparecida ya hace algunos años ${ }^{38}$, a la que refiero al lector interesado en el análisis jurídico penal de los diversos matices de esta cuestion interpretativa.

El tema que nos proponemos tampoco es exclusivo del mero avance de la ciencia como valor en si mismo, ya que como sabemos la investigación en el campo genético no sólo está impulsada por el valioso fin del avance de la humanidad, o para mitigar el dolor, sino también de intereses económicos gigantescos, que empenan muchos esfuerzos en desarrollar técnicas que permitan, por un lado, abaratar costos de producción de medicamentos, sino también preparar aquellas que permitan consolidar los medios de producción en aquellos que manejan estas complicadas materias.

La evaluación de los bienes jurídicos en juego no resulta, como vemos, simplemente de la contrastación de la dignidad humana frente a fines colectivos de investigación e información, tambien intervienen evidentes intereses económicos de consorcios médicos y farmacéuticos, que hacen muy dificil trabajar en un terreno libre de prejuicios y preconceptos teñidos de estos aspectos economicos, de indudable trascendencia, dicho sea de paso.

A este respecto, hemos visto como los mismos cientificos, conscierites de las consecuencias de sus investigaciones y hallazgos, han buscado limites para sus investigaciones, tal y como ocurrió en 1975 con la asi denominada "moratoria de Asilomar", en California, donde los científicos que investigaban el ADN y sus interrelaciones, plantearon una serie de restricciones a los experimentos que tuvieran que ver con la ingenieria genética.

El fin no justifica los medios, y mucho menos cuando está de por medio la dignidad de la persona humana. La investigación cientifica no es un fin en si misma, y por más que puedan defenderse racionalmente los argumentos de ciertos tipos de eugenesia, su impacto en la persona es de tal magnitud que resultarian injustificables constitucionalmente. De ahi que suela prohibirse la experimentación genética para el mejoramiento de la raza. La eliminación de seres humanos con la esperanza de que ayude a mejorar la vida de otros no puede ser

${ }^{35}$ Llobet, Javier, La Prisión Preventiva, San José, Costa Rica, 1998. 
justificable, no sólo por los parámetros de normalidad que son utilizados, sino tambiên porque lleva implícita una decision de poder sobre otros.

El uso de los así denominados "embriones supernumerarios", es decir, de embriones producidos en cantidad superior a la necesaria para ser implantados en el útero materno, implica que alsunos de ellos serán destruidos si no resultan útiles a los procedimientos indicados o consentidos. E1 uso de estos embriones implica, de hecho, la objetivización de vidas humanas para fines de experimentación. Kant lo decia con particular lucidez cuando aludía a la cosificación posible del ser humano. La persona debe ser considerada siempre, en todas las acciones, como un fin en sí misma.

De esta forma el bien juridico más importante protegido en la investigaciôn genética es la vida, pero también la dignidad.

El prelegislador costarricense planteó, siguiendo las líneas del derecho comparado, antes relacionadas, un castigo para las conductas de "manipulación genética". Los articulos planteados son el 131 y 132 del Proyecto presentado a la Asamblea Legislativa, Comisiôn de Asuntos Jurídicos, en el mes de junio de 2002, ya dictaminado.

El artículo 132 del Proyecto de Código Penal, como puede observarse, castiga la acción cle alterar "... el tipo de la estructura vital o el genotipo por manipulación de genes humanos con finalidades distintas a las terapéuticas". La intención del legislador es claramente castigar las intervenciones -distintas a las terapéuticas- en la estructura vital y en el genotipo del ser humano.

Esta acción de "alterar" consiste precisamente en eso: cambiar, transformar, intervenir o de cualquier manera trastocar los elementos básicos sobre los cuales se plantea la condición de ser humano.

La doctrina ha concedido una especial atención al tema, cuando concede en casi todos sus argumentos, que sea posible la alteración de esas células germinales con fines terapéuticos, para tratar de lograr la modificación de genes afectados, curando o previniendo malformaciones o enfermedades.

Por la via antes indicada se ha pretendido, por ejemplo, que las técnicas asi denominadas de terapia germinal, permitan curar al individuo portador, pero también a su descendencia, lo que abre la puerta a una posible manipulacion genética ilicita. Distinto es que se trabaje con células somáticas, que tienen importantes funciones, pero que no implican alteraciones al patrimonio genético del individuo. 
Con el fin de evitar el "eugenismo", resulta indispensable tener claro cuáles son las finalidades terapéuticas y cuáles son las enfermedades a ser tratadas (actualmente se conocen unas dos mil enfermedades transmisibles genéticamente), con el fin de que por la puerta grande de lo terapeutico se permitan meras correcciones de desviaciones de la normalidad genética.

Esto último implica que la técnica se aplique de manera que el embrión no sufra daño alguno y se pueda corregir el gen defectuoso que pueda ocasionar el mal que se pretende evitar.

La clonación está especialmente castigada en el párrafo segundo de este articulo 131. Sin embargo, el legislador incluyó otro tipo de intervenciones en el genoma que pudieran crear híbridos humanos o tambièn generar la clonación. Tambièn las actividades científicas dirigidas a la selección de raza han sido previstas como punibles, siendo esto una importante manifestación de la tendencia del prelegislador frente a los experimentos de selección de seres humanos con criterios que afecten la dignidad.

El artículo 132 prevé la "manipulación genética agravada", la cual debe ser utilizada para la producción de armas biológicas o exterminadoras de la raza humana.

El camino seguido en la protección de la vida ha quedado enmarcado en la amplísima protección que ofrece el ordenamiento juridico a esta base de nuestro acuerdo constitucional, y la lucha por su tutela continuará.

\section{b. E1 terrorismo}

Como bien se ha dicho a partir de Ios atentados terroristas en los Estados Unidos de América, España e Inglaterra, en los últimos años, no hay duda que el terrorismo es y seguirá siendo uno de los grandes problemas politico criminales de las sociedades desarrolladas, quizá no sólo a 10 largo de este siglo XXI. Las condiciones existen para que este problema se convierta en un verdadero elemento justificador de un modelo de derecho penal para toda esta centuria.

El fenómeno del terrorismo implica tres elementos de indudable valor para su caracterización, a saber: a) su estructura organizativa; b) su fuerte componente ideológico, político o religioso; y c) la instrumentalización que hace de la violencia como estrategia para alcanzar los objetivos ideológicos que persigue. Estos elementos ayudan a apartar el fantasma, siempre presente, en las discusiones del terrorismo como un concepto 
sin definición ni contornos, que ayuda a penar cualquier tipo de forma de confrontación con el status quo, aun cuando esté ayuno de violencia y coacción. Como to deciamos más atrás, la democracia vive de la tensión entre diversos grupos, incluso aquellos con ideas radicales para su cambio y transformación, y no habria justificacion para su castigo penal, si sus métodos no incluyen vias de violencia y fuerza.

A pesar de lo anterior, la tendencia internacional de combate al terrorismo vuelve sobre la vieja lógica de que contra él todo vale. E1 acento está quizá en las actividades financieras que permiten su movimiento global, por lo que no es de extrañar el interés de la reciente Convención contra el Terrorismo que impulsa la Organización de Estados Americanos, en impulsar, principalmente, el castigo de la legitimación de activos para fines de terrorismo.

Los Códigos Penales de la región hacen un acento en la creación de sentimientos de terror y amenaza en la población, pero mediante la comisión de hechos delictivos comunes como el delito de Daños, el Homicidio, el Secuestro Extorsivo, el Incendio y la Explosión. Esta vinculación a los delitos tradicionales permite, en primer lugar, concentrar los esfuerzos en focalizar la persecución penal del terrorismo, pero desmitificandola de su mera condición de conducta disidente. Por otra parte, permite vincular los eventuales fiujos y reflujos de la presión internacional por el castigo del terrorismo a un catálogo de clelitos ya previsto en la legislación. La persecución de los fines ideológicos, ya sea de carácter político y religioso, que se mencionan como uno de los elementos característicos de la regulación del terrorismo, se establece, por ejemplo en el proyecto costarricense, como una forma de agravación de los hechos delictivos antes mencionados. De esta forma cs posible ofrecer la ansiada regulación sin perder, en el proceso, importantes garantias derivadas del Estado de Derecho, que forman parten consustancial de nuestra cultura, $y$ son indisponibles ${ }^{39}$.

\section{c. La Autodeterminación Informativa como un Bien Juridico penalmente tutelado}

Los cambios sufridos por el derecho penal, el cual ha tenido que enfrentarse al grave problema de las tecnologias de la información y de la comunicación, se ha vestido con los ropajes del progreso y el desarrollo social, y nadie espera de ellas amenazas ni lesiones. Ha traido con ello,

${ }^{39}$ Un análisis profundo de algunos de estos elementos "indisponibles" presentes en el proceso penal puede encontrarse en Hassemer, Winfried, Unverfügbares im Strafprozess, en: Hassener, Strafen, op. cit., pp. 87. ys. 
segûn sus impulsores, mayor cercanía y menos soledad, más posibilidades de conocimiento y hasta de democracia.

Sin embargo, las trompetas de su advenimiento han anunciado tambien sutiles peligros para la vida de convivencia y para el ejercicio de las libertades públicas en una sociedad profundamente marcada por el signo tecnológico.

Esta sociedad de la información y del conocimiento ostenta la característica de la homogenización y de una cultura global. Las diferencias culturales van eliminándose con el sutil traslado de costumbres, gustos y hasta ocupaciones a lugares separados por tremendas distancias.

No obstante, el mayor peligro de estas tecnologias está representado por los enormes poderes que utilizan, los cuales pueden ser utilizados para alcanzar fines loables en el Estado Social, pero también para el control y el perfilado de ciudadanos, y para alcanzar objetivos de seguridad que antes hubieran requericto métodos violentos y altamente lesivos.

Las tecnologias de la información y la comunicación permiten la observación de las personas en todas sus infinitas singularidades y recopilar información sobre ellas de manera imperceptible. Casi cualquier actividad de las personas puede ser seguida y escrutada con poderosos programas de computaciôn que llevan registro de sus gustos, apetencias, costumbres de gasto, escogencias intelectuales, religiosas o politicas, prácticas sexuales, etc. Basta para ello, simplemente, que la persona utilice los medios que precisamente le garantizan una vida sin complicaciones, fâcil y despreocupada.

La respuesta a los problemas del procesamiento de datos personales en Costa Rica se ha manifestado, exclusivamente, en la interposición de recursos de amparo, la mayor parte de ellos caracterizados por ser reclamos por la inclusión de datos incorrectos, imprecisos o inexactos sobre el historial crediticio del impugnante.

Lo anterior puede llevar a la conclusión preliminar de que el ambito de tutela de la intimidad y privacidad del ciudadano costarricense tiene una única sensibilidad: la de referirse de manera directa a la interacción económica a la "autodeterminación financiera" de la persona, y no necesariamente a los muchos otros ámbitos en que se desarrolla la personalidad de los costarricenses y que son, por derecho propio las. áreas usualmente vinculadas a la discusión legislativa y doctrinal del derecho a la autodeterminación informativa.

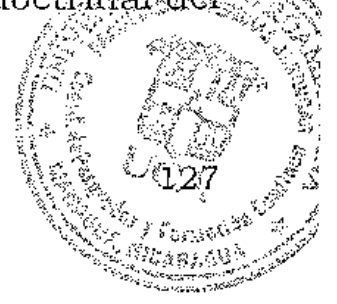


En todo caso, resulta claro y evidente que la tarea de tutela ha correspondido directamente a la Sala Constitucional, la cual ha realizado un trabajo de interpretación muy cuidadoso, que ha permitido un rápido proceso de incorporación del clerecho a la autodeterminación informativa al bagaje conceptual de nuestra jurisprudencia constitucional.

En la literatura latinoamericana es recurrente la referencia al habeas data, como forma de tutela de los ciudadanos frente al tratamiento de sus datos personales.

La vinculación del habeas data con el habeas corpus es mucho más que casual, y puede encontrarse literatura que defiende un concepto de "habeas data" como una acciôn similar al "habeas corpus", esto es, que en lugar de "traer el cuerpo", se trata de "traer los datos". Qué se hará con ellos y qué amplitud de tutela se ofrecerá, dependerá en casi todos los casos de la regulación normativa especifica o de la interpretación que den los Tribunales, usualmente constitucionales, a la cuestión.

Suele vincularse a su núcleo de tutela los derechos a la honra, a la buena reputacion, a la intimidad y al derecho a informarse ${ }^{41}$.

En la discusión del problema del procesamiento de datos en América Latina surge casi por asociación inmediata el concepto de "habeas data". Derivado en gran medida del concepto de "habeas corpus", el habeas data pretencle hacer referencia a la posibilidad jurídica de proteger el derecho de los ciudadanos a acceder a las informaciones personales que se encuentren disponibles en registros magnéticos y manuales con el fin cle ser revisados, y si representan para la persona un perjuicio, también el de ser corregidos o eliminados.

Debe insistirse que no se trata de un derecho del ciudadano a poseer los datos, ni tampoco de exigirlos como si se tratara de un ejercicio derivado del derecho a la propiedad. Se trata más bien de instrumentar una verdadera garantia procedimiental para que realice un derecho sustantivo que a su vez intenta proteger el derecho del ciudadano a saber quiên, cuándo, con qué fines y en qué circunstancias toma contacto

\footnotetext{
* Sagués, Néstor Pedro, El Habeas Data: Alcances y Problemática, en: Sánchez, Alberto, El derecho público actual. Homenaje al Prof. Dr. Pablo A. Ramella, Buenos Aires, Depalma, 1994, p. I79, cfr. También Chiriboga Zanbrano, Galo, La acción de amparo y de hábeas data: garantias de los derechos constitucionales y su nueva realidad jurtdica, en: http://www. ldis.org.ec/amparo/hab.htun

${ }^{* 1}$ Así, por ejemplo, Chiriboga, La Acción, op. cit. La Constitución Federal Brasileña considera incluidos dentro del ámbito de tutela del habeas data, tanto a la vida privada, a la honra, el derecho a la imagen, y concentra el ámbito e tutela a las informaciones contenidas en bancos de datos pertenecientes a entidades públicas o de carácter público, lo que está previsto cr el Art. $5^{\circ}$, LXXII de la actual Carta Magna brasileña.
} 
con sus datos personales. Esta articulacion suele ser dificil, ya que el habeas data no es más que una garantía procedimental, esto es una garantia para acudir a una determinada via y ahi solicitar los datos o las informaciones que se entiende son lesivas a los derechos protegidos, y como pretensión solicitar la anulación, borrado, obstrucción o corrección de los datos que afectan a la persona. Se trata, entonces, de un derecho reactivo y no de uno preventivo. Funciona cuando ya ha sucedido un daño, que puede ser, en algunos casos de incalculables proporciones, por la afectación que puede recibir una persona al producirse interconexiones automáticas de los bancos de datos

Concebir al habeas data como un derecho absoluto sobre los datos o un medio procesal para ejercer un poder "cuasi" patrimonial sobre ellos, seria incorrecto. Tan incorrecto, como concebir a la autodeterminacionn informativa como otra forma para el derecho a poseer los datos. El derecho a la autodeterminación informativa no le concede al ciudadano un definitivo y absoluto poder sobre sus datos ${ }^{42}$, sino el derecho a estar informado del procesamiento de los datos y de los fines que se pretende alcanzar, junto con los derechos de acceso, corrección o eliminación en caso de que se cause un perjuicio. Aquí se pone el interés, entonces, en la "autodecision" o en la "autodeterminación" del individuo, lo que se desea es garantizarle su posibilidad de participación como ciudadano frente a un procesamiento de datos personales que lo puede hacer transparente para el control y reducirlo a un mero objeto del ambiente informativo.

Desgraciadamente, el habeas data latinoamericano se ha concentrado en un derecho reactivo de indole procesal constitucional ${ }^{* 3}$, y decimos desgraciadamente, porque ha hecho que la figura depende de la amplitud y generosidad de la interpretación de los tribunales constitucionales de los diversos supuestos o constelaciones de casos. Los modelos europeos y norteamericanos se inspiran en diversos puntos de partida. En el caso europeo, como ya hemos visto, se ha puesto el acento en establecer deberes, la mayor parte de ellos preventivos, para salvaguardar a la persona antes de que suceda una posible afectación a su derecho a la autodeterminación informativa. Los Estados Unidos han preferido tutelar acciones individuales bajo el amparo de una ley que defiende especificamente la privacidad de los hogares y de las personas ${ }^{44}$.

12 Scholz, Rupert y Pitschas, Rainer, Informationelle Selbstbestimmung und staatiche Informutionsverantwortung, Berlin, Dunker und Humblot, 1984, p. 27.

${ }^{43}$ Sobre el carácter indudablemente constitucional del habeas data efr, en lugar de muchos otros: Gozaini, Osvaldo Alfredo, El proceso de habeas data en la nueva ley, en: litp://mw abogartecomarthabeasdatal him

4t Así Gozáni, Proceso, op. Cit 
El habeas data, en nuestra concepción, se queda a medio camino, entre la tutela integral de los ámbitos de autodeterminación del ser humano, y la posibilidad de construir una tutela preventiva de las lesiones que como inmensos riesgos se ciernen sobre las posiciones juridicas de los ciudadanos en una sociedad orientada a la información. No debe dejarse de lado, que los derechos de la tercera generación ${ }^{45}$, en la clasificación de Pérez Luño, surgen ante el fenómeno inevitable de la "contaminación" provocada por ciertos usos de las nuevas tecnologias ${ }^{45}$. El derecho a la autodeterminación informativa es uno de estos derechos, y exige que la regulación normativa sea coherente con su naturaleza. Es por ello que deben tomarse en cuenta no sólo los derechos de acceso y control, sino tambièn previsiones de carácter técnico que salvaguarden, con efectividad, los derechos involucrados ${ }^{47}$.

La inevitable limitación que ofrece una garantia exclusiva en el ámbito procedimental se manifiesta, muy especialmente en Brasil, donde la Constitución misma limita el ejercicio del habeas data contra incorrectos datos e informaciones contenidos en bancos de datos públicos, lo que es una decisión incorrecta, si se le evalúa, por ejemplo, desde la perspectiva del cambio de posiciones acaecido en la década de los ochenta y noventa del pasado siglo, cuando los privados adquirieron un enorme poder informático y lo utilizaron para vender datos personales y con ello generar un riesgo insospechado para la capacidad de autodeterminación de las personas.

El prelegislador costarricense, tomando en cuenta todos estos problemas, y teniendo como punto de partida una vigorosa jurisprudencia constitucional, ha introduciclo, por ello, un Capitulo sobre Delitos contra la Autodeterminación Informativa en el Proyecto de Código Penal.

${ }^{45}$ Las leyes de la primera generación serían, según este autor, las leyes que se concentraban en una autorización previa de los bancos de datos, lo que tenia sentido ya que estas leyes surgieron cuando el procesamjento de datos era centralizado, los equipos voluminosos y fácilmente localizables. Luego surgieron las „leyes de la segunda gencración", las cuales pusieron el énfasis en los dalos sensibles, a fin de evitar daños a la privacidad y ofrecer alguna garantía frente a posibles prácticas discriminatorias que pudieran tener su origen en el uso de esos datos, ,sensibles". L,uego vendrian las leyes de la terceta generación, interesadas en el "uso" y "funcionalidad" de las informaciones. Aquá ubica Pérer Luño, por cjemplo, a la LORTAD española. Cft. Pércz Luño, La Tutela de Ja Libertad Informática, op. cit., pp. 97-98.

"Cfr. Pérez Luno, La Tutela de la Libertad Informática, op. cit., p. 97.

"Esta unificación entre herramientas técnicas y protección de datos es promocionada, por ejemplo, por Hassemer, Winfied, Uber die Absehbare Zukunft des Datenschutzes, $K J$ (Alemania) 1996, pp. 103 y ss. 
Al respecto se ha optado por una protección del Bien Juridico "Intimidad" que se podria denominar "extendida", con el fin de superar la tradicional concepción del "secreto" como valor en símismo.

Una tutela moderna de la Intimidad, en el momento actual de desarrollo tecnológico, no puede concentrarse a la protección de "papeles o documentos privados" y a utilizar verbos tales como el mero "imponerse" de su contenicio; o de abrir o leer correspondencia ajena; o de tener acceso a comunicaciones telegráficas, telefónicas; o de realizar grabaciones magnetofónicas sin el consentimiento de quien es objeto de la grabación; o hacer uso indebido de tales cintas.

Este punto de partida revela los evidentes beneficios de emplear una metodologia de construcción de tipos penales, que utilice como herramienta la perspectiva de tutela de bienes juridicos. Esta metodologia ofrece muchas ventajas: por una parte, permite que el intêrprete pueda comprender verdaderamente los alcances de la prohibición, verificando al mismo tiempo el cumplimiento de las garantias del principio de legalidad que ordenan un cierto tipo de cuidados legislativos a la hora de la redacción de los tipos penales. Por otra parte, señala las falencias - brechas de tutela que se van produciendo al mantenerse ciertas redacciones tipicas que ya no responden a los fines originales de protección, ya sea porque tales intereses o entes de convivencia han dejado de tener un grado de validez tal que justifiquen la reacción penal, o, por el contrario, cuando su grado de "contaminación" producto de la interacción social y del aumento de la complejidad del acontecer colectivo, hagan que sus marcos de tutela se encuentren agotados, y por ende requieran de un ajuste proporcional y razonable de acuerdo a la coyuntura en la que se redacta el tipo penal.

El Proyecto colma, aunque si bien parcialmente, una importantisima laguna de tutela del ordenamiento juridico, al intentar ampliar el ámbito de cobertura de la tuțela penal al ámbito de la "intimidad" conocido como "ibertad informática" o "derecho a la autodeterminación informativa".

El Capitulo comienza con un tipo penal que castiga el "Tratamiento Ilícito de Datos Personales y Comunicaciones", en donde hay un elemento normativo muy importante referido a un objeto material real de la acción que son: "las comunicaciones, imágenes o datos de otra persona física o juridica no públicos o notorios". Estos "datos" pueden estar "registrados" en "ficheros", "soportes informáticos", en "programas de computadoras o en sus bases de datos", y en cualquier otro tipo de archivo, público o privado. Así la tutela penal se extiende no sólo al tráfago de las comunicaciones personales por vía telefónica, cablegráfica o telegráfica 
o a la custodia de documentos privados en archivadores y otros muebles, sino que ahora es posible encontrar cobertura cle tutela al "secreto" y a la "intimidad" también cuando se trata del "apoderamiento" de datos personales, o cuando alguien intente "imponerse" de su contenido en ficheros públicos o privados.

La persona merece protección en el momento actual del desarrollo tecnológico, ya que el riesgo más grande en el procesamiento de datos personales se produce frente a la posibilidad de la creación de perfiles de las personas o de los grupos sociales a los que pertenecen, asi como tambien a hacer transparentes sus personalidades para los órganos de control o para los sujetos privados que también realizan un importante proceso de recoleccion y tratamiento de datos personales con fines de tipo económico y político.

Estos aspectos hacen que la "intimidad" se enfrente hoy en día a peligros enormes, que ya no refieren principalmente a daños que afecten bienes jurídicos de carácter patrimonial, sino también a los derechos a la participación política y social de los individuos, lo que lleva, por supuesto, a la necesidad de tutelar tambièn esta faceta "política" de la "intimidad".

Existen dificultades para determinar con un catálogo especifico de datos personales sensibles, ya que la idea de dato referido a la persona es muy amplio ya que incluye también los números de identificación del ciudadano, por ejemplo, su numero de pasaporte o su licencia de conducir o su documento de identidad, y en general juicios de valor y manifestaciones de terceros sobre esa persona.

La doctrina internacional ha indicado, adicionalmente, que una determinación especifica de cuáles datos sensibles es siempre limitada, toda vez que algunos datos que hoy podriamos considerar sin importancia, mañana podrian adquirir una relevancia enorme. Esto es un tema de induclable repercusión para la reforma penal que se plantea, al igual que lo indicado sobre los datos estadísticos, los cuales, a inicio de los años setenta figuraban como datos totalmente anónimos, pero que luego con los años, se ha descubierto que es posible regresar los datos estadisticos a las personas que en un inicio los dieron o, por lo menos, a los grupos en concreto a los que hacen referencia, por lo que el dato estadistico trae una problemática nueva de induđable interés para el legislador, sobre todo en materia de la relación entre el derecho a la autodeterminaciôn informativa y el derecho a la investigacion científica.

Los datos sensibles gozan, por supuesto, de una enorme dinamicidad por lo que es recomendable siempre pensar en la conveniencia de que 
una definición legal no agote su función garantista de la autodeterminación del ciudadano, evitando su anulación como individuo en la sociedad informatizada, provocando por ejemplo que se le estigmatice o se le discrimine de cualquier manera .

Se han introducido tambiên circunstancias agravantes especificas en cuanto a posibles lesiones provenientes de los encargados del tratamiento de la información, y sobre todo de las que provengan de un funcionario público, que valiéndose de su condición y acceso a los datos personales y "secretos" del cizdadano realice las acciones contempladas en los tipos penales de este Capitulo.

En uno de los articulos se introduce una circunstancia agravante cuando se trate de una acción realizada por las personas a cargo de los ficheros, de los soportes informáticos, las cuales, en el derecho comparado, se ven compelidas al seguimiento de estrechos códigos deontológicos que contienen los deberes de sigilo y seguridad de los datos, principalmente, asi como también otras garantias en beneficio del ciudadano que es objeto de un procesamiento electrônico de sus datos, que por razón del mismo debe tener una "confidencialidad compartida", esto es: a los funcionarios encargados del tratamiento de la información.

En este Capitulo se pone especial énfasis al deber de los funcionarios públicos de velar por el secreto y la intimidad de los ciudadanos, poniendo correctamente como limite de la tipicidad a la ley, cuando ésta permita el acceso a los datos personales con un fin proporcional (adecuado, necesario, y aceptable en cuanto que no haya otro menos lesivo), con expresión clara del objeto del tratamien to y obligando a una sujeción estrecha al fin para el cual se previó la colecta de los datos.

En el derecho comparado es posible encontrar en el ámbito de responsabilidad de los funcionaxios una especial rigurosidad sancionatoria, con una serie de penas conjuntas y accesorias dirigidas a impedir que los funcionarios que han violado la intimidad de los ciudadanos puedan volver a hacerlo en un puesto similar. En relación con el problema de los funcionarios públicos debe agregarse que mucho del carácter de garantia del derecho a la autodeterminaciôn informativa depende de la actividad de los "responsables de los ficheros" tanto públicos como privados en controlar y hacer obligatorio el fin legal de la colecta de los datos, haciendo imposible la interconexión de los bancos de datos o la comparación de los mismos, cuando aquello no esté previsto para el cumplimiento del fin legal, o para que esta recolección se haga a "beneficio de inventario", es decir, con el fin de hacer una acumulación de datos que puedan tener una utilidad posterior no definida. 
Existe evidentemente una dependencia del derecho penal de una definición legal o constitucional del derecho a la autodeterminación informativa, es por ello que debe continuarse este camino hacia una mayor tutela de la persona frente al tratamiento electrónico y manual de sus datos personales, a fin de superar el apego a un concepto tradicional y patrimonialista de la protección de la intimidad y lograr un estándar adecuado de protección, que además es exigido para ubicar a Costa Rica dentro del concierto de las naciones que tienen ya una serie de regulaciones para garantizar la realización efectiva de la Autodeterminación Informativa ${ }^{48}$.

\section{d. El diagnóstico}

Mucho del detalle de los caminos emprendidos en Europa, en especial sobre la situación espiritual de algunas de las reformas sufridas en la legislación sustantiva, y en los modelos de incriminación de la Parte Especial, coincide con los problemas y preocupaciones que Costa Rica ha afrontado y seguirá afrontando.

La década de final de siglo y los años iniciales del presente han estado marcados por diversas circunstancias económicas y politicas, por hechos delictivos atroces que han conmovido a la opinión püblica, y diversos fenomenos sociales, que han obligado al legislador a repensar algunas instituciones, a ponderar de nuevo los montos penales, y a replantear los mecanismos de reacción del ius puniendi, $y$, por supuesto, a reconstruir la línea general de la reforma. Pensamos que ningün proceso de transformación de la legislación penal puede ser inmune a estos procesos, como tampoco a los flujos y reflujos de las tendencias de ley y orden. Lo que es importante, es que se mantenga una línea politica criminal, que sea ponderada, distanciada de los fenómenos pero comprensiva de los procesos sociales que van generando conductas que eventulalmente podrian ser calificadas como lesivas de bienes jurídicos trascendentales para la convivencia social.

\footnotetext{
4. El camino hacia una tutela integral de la autodeterminación informativa parece haberse iniciado con la presentación al cauce legislativo de un Proyecto de Ley para la Protección de la Persona frente al Tratamiento de sus Datos Personales por parte de un grupo de diputados y diputadas de diferentes fracciones, en una iniciativa de ley planteada por la Diputada Margarita Penón. Este proyecto incorpora muy valiosas consideraciones del derecho comparado y apuesta fuertemente a un sistema mix to de tutcla, donde se potencia la prevención y la fonnación de un cultura por parte de las administraciones y de los particulares. Hemos comentado ampliamente este proyecto, y la coyuntura que le precede en: Chirino Sánchez, Alfredo y Carvajal, Marvin, El Camino hacia la protección de ta persona frente al tratamiento de datos personales en Costa Rica, en: Revista de Derecho Constitucional, San José, Costa Riea, cn prensa.
} 
Al respecto se discute sobre si existe, realmente, una "politica criminal" en Costa Rica, o a si estamos más bien en presencia de "reacciones constantes" a los fenómenos criminales que más alarman al colectivo social, hipotesis en la cual no existiria un acercamiento uniforme al delito, sino únicamente, una reacción simbólica a las conductas criminosas que generan, de alguna manera, la atención de los medios y de la opinión pública.

Esta perspectiva de análisis, esencialmente comprometida con una reducción del uso del derecho penal como instrumento de conducción social, no gozaba de buena coyuntura politica. Sus inicios, especialmente dedicados a incorporar el capitulo de penas alternativas en el Código Penal, tuvieron que enfrentar la propuesta legislativa de aumentar el monto maximo de la pena privativa de libertad de 25 a 50 años de prisión, lo que daba al traste, al menos en la dinámica de la dosimetria penal, con cualquier esperanza de construir un enfoque de resocialización, sobre todo para aquellos delitos amenazados con altas penas de privación de libertad.

Afortunadamente este desacierto no hizo fracasar las buenas intenciones de reforma del derecho sustantivo y la propuesta generaria interés en circulos académicos y judiciales, adquiriendo el ímpetu necesario para acometer la dificil tarea de proponer un enfoque integral de reforma al Código Penal.

La orientacion a las consecuencias del funcionarniento del sistema de justicia penal, el enfoque criminológico de muchos de los fenómenos delictuales, y el estudio concienzudo de los paliativos existentes en el derecho comparado, deberian de ser asignaturas básicas de todo proceso de reflexión encaminado a postular una reforma de la ley penal. Así lo han indicado puntualmente criminologos y penalistas costarticenses. No obstante, se nota, en los diversos procesos de reforma centroamericanos, que las postulaciones legislativas no suelen tener un sólido sustento en una observación científica de los fenómenos delictuales.

Alguna investigación existe sobre el tema contravencional, el sistema de penas alternativas, de dias multa, sobre la politica criminal en materia de psicotrópicos y estupefacientes $y$, sobre delitos económicos, entre otros, pero sin dar datos de mucha utilidad práctica para las decisiones legiferantes.

La ausencia de estudios criminológicos sobre los diversos tipos de criminalidad, y sobre los efectos de los diversos intentos de reacción 
penal, hacen que la politica criminal no sea más que una labor de pruebaerror, totalmente inidónea para generar los procesos que se requieren.

En el horizonte se perfilan dos modelos ciaros de política Criminal. Por una parte, contamos con el diseño politico de un derecho penal que pretende seguir ofreciendo efectos simbólicos, en la medida que persigue seguridad y eficacia. Este modelo subsistirá en la medida que aceptemos las enormes disfunciones en tërminos de garantias que este conlleva. Se trata de un modelo que flexibiliza los esquemas de imputación subjetiva, plantea modificaciones importantes en la teoria del injusto, y traslada algunas de sus visiones "eficientistas" al principio de culpabilidad y al del merecimiento de pena. Es un derecho penal de "primera ratio", que se parapeta tras bienes juridicos supraindividuales que sintetizan una gran cantidad de aspiraciones colectivas que se considera deben prevalecer sobre los derechos subjetivos de los ciudadanos. En esencia, este modeio implica "renormativizaciôn" del derecho penal y la sustitución de los bienes jurídicos. Estos últimos no serán mâs faros de iluminación de la creación y funcionamiento del sistema penal.

De otra parte, contamos con un modelo politico criminal que es consciente de las consecuencias de las decisiones criminalizantes. En el diseño de sus postulados parte aun de los principios de intervención minima, de protección de bienes jurídicos y de lesividad. Para esta construcción, el derecho penal debe ser consciente de sus limites constitucionales y permanecer como un verdadero reflejo de los grandes objetivos del Estado social y democrático de Derecho. Su vocación no es alcanzar una revaloración normativa, ni tratar de rescatar la confianza normativa, afectada profundamente por las expectativas insatisfechas por la conducta criminal. El derecho penal que surge de este modelo funciona como "ultima ratio" y reacciona alli donde es necesario para mantener las condiciones básicas del contrato social. En la medida de lo posible, sigue vinculado a un eje de comparacion que se denomina "clásico", que nosotros hemos preferido llamar "constitucional".

Ante nosotros se presentan estas dos opciones, y las circunstancias globales y los temores y riesgos de las sociedades postmodernas. La decision implica, sin duda, el diseño del proyecto social costarricense del futuro. Deseémonos sabicuria para saber escoger. 